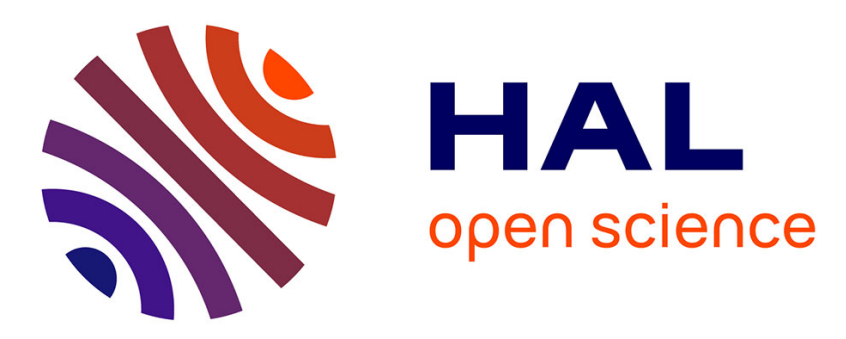

\title{
Understanding Entheseal Changes: Definition and Life Course Changes
}

\author{
Sébastien Villotte, Christopher J. Knüsel
}

\section{To cite this version:}

Sébastien Villotte, Christopher J. Knüsel. Understanding Entheseal Changes: Definition and Life Course Changes. International Journal of Osteoarchaeology, 2013, Entheseal Changes and Occupation: Technical and Theoretical Advances and Their Applications, 23 (2), pp.135-146. 10.1002/oa.2289 . hal-03147090

\section{HAL Id: hal-03147090 https://hal.science/hal-03147090}

Submitted on 19 Feb 2021

HAL is a multi-disciplinary open access archive for the deposit and dissemination of scientific research documents, whether they are published or not. The documents may come from teaching and research institutions in France or abroad, or from public or private research centers.
L'archive ouverte pluridisciplinaire HAL, est destinée au dépôt et à la diffusion de documents scientifiques de niveau recherche, publiés ou non, émanant des établissements d'enseignement et de recherche français ou étrangers, des laboratoires publics ou privés. 


\section{Understanding Entheseal Changes: Definition and Life Course Changes}

\begin{tabular}{|r|l|}
\hline Journal: & International Journal of Osteoarchaeology \\
\hline Manuscript ID: & OA-12-0089.R1 \\
\hline Wiley - Manuscript type: & Commentary \\
\hline Date Submitted by the Author: & $\mathrm{n} / \mathrm{a}$ \\
\hline Complete List of Authors: & $\begin{array}{l}\text { Villotte, Sébastien; University of Bradford, AGES } \\
\text { Knusel, Chris; University of Exeter, Department of Archaeology }\end{array}$ \\
\hline Keywords: & $\begin{array}{l}\text { entheses, enthesopathy, Musculoskeletal Stress Markers (MSM), } \\
\text { senescence, activity, hormones, animal models, clinical studies }\end{array}$ \\
\hline
\end{tabular}

SCHOLARONE $^{\text {m }}$
Manuscripts 
1

2

3

4

5

6

7

8

9

10

11

12

13

14

15

16

17

18

19

20

21

22

23

24

25

26

27

28

29

30

31

32

33

34

35

36

37

38

39

40

41

42

43

44

45

46

47

48

49

50

51

52

53

54

55

56

57

58

59

60

Title:

Understanding Entheseal Changes: Definition and Life Course Changes

Short title:

Understanding Entheseal Changes

Keywords: entheses; enthesopathy; Musculoskeletal Stress Markers (MSM); senescence; activity; hormones; animal models; clinical studies

Authors:

Villotte S.

Biological Anthropology Research Centre

Division of Archaeological, Geographical \& Environmental Sciences

Phoenix SW Building

University of Bradford

Bradford, West Yorkshire, BD7 1DP, UK

Telephone: $+44(0) 1274233550$

Emil Address: s.villotte@bradford.ac.uk

and

Knüsel C.J.

Department of Archaeology,

University of Exeter,

Laver Building,

North Park Road,

Exeter, Devon, EX4 4QE, UK

Telephone: +44 (0)1392 262491

E-mail Address: c.j.knusel@exeter.ac.uk 


\begin{abstract}
:
Over the past two decades, many articles have been published on entheseal changes (usually called "Musculoskeletal Stress Markers") as activity markers in past societies. Oversimplified methods and over-interpretation of past activities have generated robust critiques of research results in this area of enquiry. While some significant improvements regarding the recording systems for entheseal changes have been applied more recently, many bioarchaeologists appear not yet to be fully aware of the multi-factorial aetiology of these alterations. In this article, we review the anatomical and clinical literature to discuss some of the difficulties associated with the recording of entheseal changes and the multiple factors leading to their appearance in the human skeleton. Thus far fibrocartilagenous entheses appear to hold more promise for activity-related reconstruction than do fibrous ones, but these relationships remain an area of active research interest.
\end{abstract}

Introduction

La Cava (1959) appears to have been first to use the term "enthesis" for creating the word "enthesitis" to designate the inflammation of tendinous attachments. Subsequently, Ball (1971) and Niepel and Sit'Aj (1979) suggested using the words "enthesis" to designate the area where a tendon, a capsule or a ligament attaches to bone and "enthesopathy" to indicate pathological changes of this structure. "Enthesis" and "enthesopathy" are commonly used today in biomedical sciences, but other terms can also be found in the literature (table 1).

\title{
TABLE 1
}

An enthesopathy can be a radiological, clinical, histological or osteological finding, and the notion of pain is not necessarily associated with its occurrence (e.g. Ball, 1971; Resnick and Niwayama, 1983; François et al., 2001). In biological anthropology, several terms are used to designate the osteological changes seen in entheses: enthesopathies (e.g. Dutour, 1986; Hawkey, 1988), muscle crests (Angel et al., 1987), musculoskeletal stress markers (Hawkey and Merbs, 1995), or muscle markings (Robb, 1998). Recently, Jurmain and Villotte (2010) 
proposed the generic and more neutral term "entheseal changes" to designate all "particular" aspects of entheses seen in skeletal material.

The interest of biological anthropologists in entheseal changes of the human skeleton is older than a century (e.g. Lane, 1887, 1888; Testut, 1889). Three main factors account for this interest. First, the areas of tendon or ligament attachment are usually easily visible on dry bones. Second, entheses exhibit a number of morphological variations, with more or less pronounced changes, such as irregularity and porosity, so changes can be scored. Finally, as entheses are regularly under heavy strain during physical activity, changes can, hypothetically, be used to reconstruct past physical activities. This type of study also has a long and contentious disciplinary history (for reviews, see Kennedy, 1989; Dutour, 2000; Jurmain et al., 2012), with some notable detractors (e.g. Jurmain, 1999; Zumwalt, 2006; Jurmain and Roberts, 2008; Alves Cardoso and Henderson, 2010) as well as supporters (e.g. Dutour, 1986; Hawkey and Merbs, 1995; Molnar, 2006; Villotte et al., 2010a, 2010b; Havelková et al., 2011).

Methodological research recently carried out by several scholars (Mariotti et al., 2004, 2007; Zumwalt, 2005; Villotte, 2006, 2009; Henderson and Gallant, 2007; Henderson et al., 2010; Villotte et al., 2010a) provides a renewed interest for the study of entheseal changes as potential markers of activity, as it can be seen, for instance, by the success of the Workshop in Musculoskeletal Stress Markers (MSM): limitations and achievements in the reconstruction of past activity patterns, held at the University of Coimbra, in Portugal ( $2^{\text {nd }}-3^{\text {rd }}$ July 2009) (Santos et al., 2011). However, this relative success could turn against itself, and one cannot entirely dismiss previous remarks on the limitations and pitfalls of this kind of study.

The purpose of this article is not to discuss the reliability of entheseal changes for the reconstruction of past activities, nor the strictly methodological aspects of this kind of study because those considerations have been largely discussed elsewhere (Dutour, 1992; Robb, 1998; Jurmain, 1999; Mariotti et al., 2004, 2007; Villotte, 2006, 2008a, 2009; Henderson and Gallant, 2007; Alves Cardoso and Henderson, 2010; Villotte et al., 2010a; Jurmain et al., 2012; Millela et al., n.d.). The goal here is rather to attempt to clarify several points to anticipate continued use of entheseal changes as potential markers of activity in past populations. This perspective is based on the following premises: the most reliable data on entheses and entheseal changes are provided by their use in the biomedical sciences (even if some studies, as case reports, have apparently little broader application), and data from 
identified skeletal collections are far better than those provided by archaeological samples because of numerous inherent biases (e.g. the effect of age and the difficulty to assess the ageat-death in archaeological samples, their unknown genetic background).

\section{Anatomical background \\ 1) Types of enthesis: a brief presentation}

Two groups of entheses can be distinguished according to the tissue type present at the skeletal attachment site: fibrocartilaginous and fibrous (Benjamin and McGonagle, 2001; Benjamin et al., 2002). Recently, the importance of this anatomical distinction for recording entheseal changes in skeletal material has been highlighted, independently, by Henderson (Henderson and Gallant, 2007; Alves Cardoso and Henderson, 2010) and by Villotte (2006, 2008a, 2009; Villotte et al., 2010a).

Briefly, fibrocartilaginous entheses occur close to joints of the long bones, but also on short bones and some parts of vertebrae; fibrous entheses occur on the diaphysis of long bones and also on the vertebral column (see tables A1 and A2 in Villotte et al., 2010a for a list of the main post-cranial fibrous and fibrocartilaginous entheses). Four histological zones are distinguished in fibrocartilaginous entheses (Cooper and Misol, 1970; Benjamin et al., 1986): 1) tendon or ligament, 2) uncalcified fibrocartilage, 3) calcified fibrocartilage, and 4) subchondral bone. Zones 2 and 3 are separated by a regular calcification front called the "tidemark". The tidemark, which is relatively rectilinear and not crossed by blood vessels, is the point at which soft tissues are removed during maceration (Benjamin et al., 1986). Contrary to fibrocartilaginous attachments, anatomical and anatomo-pathological descriptions for fibrous entheses are extremely rare. They attach soft tissues to bone directly or via a mediating layer of periosteum (Benjamin et al., 2002). The anchorage is achieved through collagen fibers from periosteum, tendon, or ligament, which are embedded into bone (François et al., 2001; de Pinieu and Forest, 2003). At fibrous entheses, blood vessels from the tendon or the ligament may anastomose with those of the bone (Dörfl, 1969).

2) Defining a "normal" and a "changed" enthesis, is it simple? 
The characteristic aspect of a healthy fibrocartilaginous enthesis is described by Benjamin and colleagues (2002: 939) in the following manner: "as the tidemark is relatively straight and the fibrocartilage zones avascular, the site of attachment in a healthy enthesis is smooth, well circumscribed and devoid of vascular foramina." This description fits well with the appearance of several attachment sites seen on the skeleton (Fig. 1). Moreover, the accurate and numerous descriptions of changes that occur in enthesopathies in living people - erosion of the calcified fibrocartilage and subchondral bone, tidemark irregularity, vascularization of the fibrocartilage, calcification and ossification of soft tissues, cysts, and avulsions can be observed in skeletal material (Villotte, 2006, 2009; Villotte et al., 2010a and clinical references therein). Thus, it seems conceivable to define a "healthy" (or "normal") fibrocartilaginous enthesis in skeletal material as a smooth, well-defined imprint on the bone, without vascular foramina, and with a regular margin, and an enthesopathy in the other cases (Villotte, 2006, 2009, Villotte et al., 2010a). However, this definition can be applied for only some fibrocartilaginous attachments; it does not work as well, for instance, for the entheses of ligamenta flava on the vertebral column (Villotte, 2006) or for small attachment sites like the insertion of the M. brachialis (pers. obs., and Mariotti, pers. comm.). In the case of the $M$. brachialis, this may be related to the relatively thin layer of uncalcified fibrocartilage at the insertion, and the fact that this muscle is already attached to the bone at birth (cf. Benjamin et al., 1992).

\section{FIGURE 1}

Regarding the paucity of clinical and anatomical data for fibrous entheses, the definition of a "normal" type is far more complex (Villotte, 2006, 2009; Alves Cardoso and Henderson, 2010). Osseous irregularity in the area of fibrous attachments is common in human skeletal remains, even in the first decades of adulthood (Villotte, 2009). Since the term "enthesopathy" implies a pathological condition, it is not appropriate to designate all of these very common and probably asymptomatic changes as pathological (Jurmain and Villotte, 2010).

3) Possible pitfalls of anatomical over-simplification

Changes in the two types of enthesis do not indicate the same phenomena, and it is to be expected that biological anthropologists will no longer combine them in a single study. 
Although the distinction between fibrous and fibrocartilaginous entheses seems clear enough, one should not forget that some amendments to their apparent distinctiveness have been made. First, some attachments are "mixed." Hems and Tillmann (2000) showed that the majority of the entheses of the masticatory muscles are of this type. Thus, the insertion of $M$. masseter is partly periosteal, partly osseous and partly fibrocartilaginous. Second, in a fibrocartilaginous enthesis, the periphery has little or no fibrocartilage (Benjamin et al., 1986, 2002). Third, fibrocartilage may exist in a small quantity at a fibrous enthesis, particularly on the metaphysis, an example of which is the M. pectoralis major insertion on the humerus (Benjamin et al., 1986, 2002). Finally, one should not forget the morphological diversity in our species. For example, the most distal part of the insertion of the M. iliopsoas, at the junction between the lesser trochanter and the femoral shaft, may correspond to the inconstant fibrous insertion of the M. iliacus (Polster et al., 2008) and this region is highly variable as a consequence (Fig. 2).

\section{FIGURE 2}

Several authors have discussed the boundaries of the concept of enthesis (for fibrocartilaginous attachments), and all agree that it cannot be reduced to the attachment of a tendon or ligament. ${ }^{1}$ In addition to the attachment zone, Niepel and Sit'Aj (1979) include under the term "enthesis", all of the following: peritenon, associated bursae, fibrous tissues, fat-pads and sesamoid bones. Benjamin and colleagues (2001, 2002, 2004) formalized this concept and suggest using "enthesis organ" for the complex consisting of these anatomical structures around the fibrocartilaginous entheses sensu stricto because fibrocartilage is almost systematically observed in these structures. It is important that biological anthropologists consider this point before scoring entheseal changes. For instance, recent methodological papers (Mariotti et al., 2004, 2007; Villotte, 2006; Henderson and Gallant, 2007; Henderson et al., 2010; Villotte et al., 2010a) do not mention bursae and whether or not bursopathies are scored. Admittedly, this is a thorny problem. Villotte (2009), perhaps wrongly, did not score bone changes that can occur at the location of bursae (Fig. 3) for several reasons: at present, data on bursopathies are still too scarce to accurately analyze the consequences on the

\footnotetext{
${ }^{1}$ Opinions differ on the structures to be associated with the enthesis sensu stricto. For instance, Fournie proposed the extension of the concept of enthesis to include amphiarthroses and diarthro-amphiarthroses (Fournié and Fournié, 1991; Fournié, 2004). First, in histological and functional terms, these joints are closer to fibrocartilaginous entheses than to true diarthroses. Second, these joints and fibrocartilaginous entheses are predilected in seronegative spondyloarthropathies.
} 
skeleton, the presence of bursae is inconstant, and their exact location varies. However, these data may be of interest in the discussion of past activities - bursae, as a part of the "enthesis organ", participate actively in the dissipation of mechanical stresses. Moreover, it should be noted that sometimes the distinction between a bony involvement of the tendon attachment site or of the bursa is difficult to establish.

\section{FIGURE 3}

Entheseal changes through life: the effects of age, hormones and activity

Trauma and micro-trauma can produce entheseal changes, among numerous others factors (Resnick and Niwayama, 1983). Clinical literature also reports the presence of entheseal changes in many diseases. The goal is not to present these conditions in detail here (listed in Henderson, 2008; Villotte, 2009), but rather to focus on lesser-known aspects of entheseal changes related to age, hormones and physical activities. However, it seems necessary to present briefly the two main causes of non-degenerative enthesopathies: spondyloarthropathies and diffuse idiopathic skeletal hyperostosis (DISH or hyperostotic disease). DISH is characterized by para-articular bridging osteophytes in the anterolateral aspect of the spine (Forestier and Rotes-Querol, 1950; Resnick et al., 1975). Exuberant bone production is seen at extra-spinal fibrocartilaginous and fibrous entheses (Resnick et al., 1975). Very early on, researchers recognized the enthesis as a primary target in ankylosing spondylitis and other spondyloarthropathies (Ball, 1971; Paolaggi et al., 1984a, 1984b). The inflammation occurs at the level of fibrocartilaginous entheses, leading to erosion of the fibrocartilage (Benjamin and McGonagle, 2001; Fournié, 2004). This erosive process is followed by deposition of reactive bone and the formation of an enthesophyte (Ball, 1971; Resnick and Niwayama, 1983). It is noteworthy that entheseal changes seen in cases of spondyloarthropathy are characterized, at least for some fibrocartilaginous entheses, by erosive lesions uncommonly seen in other individuals (Villotte and Kacki, 2009).

In studies of entheseal changes in skeletal samples with known age-at-death, age is the main etiological factor identified (Shaibani et al., 1993; Cunha and Umbelino, 1995; Mariotti et al., 
2004, 2007; Villotte, 2009; Alves Cardoso and Henderson, 2010; Villotte et al., 2010a; Niinimäki, 2011; Milella et al., 2012). However, the precise relation between age and entheseal changes remains poorly described (and in some aspects poorly understood). Properties of the entheses during skeletal immaturity are mainly described in studies of animal models and, to a lesser extent, in studies of human cadavers. For adulthood, data derive mainly from sports medicine or that associated with the aged, though the study of identified skeletal collections provides informative results.

1) Secondary ossification centres

In early development of humans and other mammals, the tendon or ligament attaches to the perichondrium (Hurov, 1986; Gao et al., 1996; Wei and Messner, 1996; Shaw et al., 2008). During growth, entheses seem to act as growth plates; the cartilage is resorbed at the inner side and produced at the outer side, possibly by metaplasia (Gao et al., 1996; Nawata et al., 2002). The classic appearance of a fibrocartilaginous enthesis (i.e. the four histological zones, see supra) appears in non-human mammals when growth slows or stops (Wei and Messner, 1996; Nawata et al., 2002; Wang et al., 2006). For instance, in the attachment zones in the rat anterior cruciate ligament, the boundary between uncalcified and calcified fibrocartilage is not clearly distinguishable before growth slows (Nawata et al., 2002). The process is not described for humans, but this progressive organization of the enthesis during growth and development could explain the lack of a clearly distinguishable area of attachment in juvenile human skeletons (Fig 4, compare with Fig. 1). Indeed, in skeletal remains, the classic appearance of a fibrocartilaginous enthesis is seen when epiphyses of short and flat bones (also called apophyses) and long bones are partially or fully fused. The most common activity-related change occurring before the complete fusion of the epiphysis is a total or a partial bony avulsion (e.g. Resnick and Niwayama, 1983; Nakanishi et al., 1996; Stevens et al., 1999; Adirim and Cheng, 2003). Consequences of these avulsions (total or partial) can be observed on the adult skeleton (Villotte et al., 2010b; Knüsel, 2012).

\section{FIGURE 4}

During adulthood, the degenerative process related to age and mechanical demands affects both the tendon and the fibrocartilaginous enthesis. Within the aging tendons, the amount of denatured collagen and proteolytic cleavage of matrix components increase (Riley, 2004). 
These changes lead to deterioration in the physical properties of the tendon (Riley, 2004), which, in turn, may favour the occurrence of mechanically induced alterations in the enthesis (Rodineau, 1991; Bard, 2003). From the sixth decade onwards, the fibrocartilaginous enthesis itself is the target of the degenerative process (Durigon and Paolaggi, 1991; Rodineau, 1991; Bard, 2003). Those degenerative changes are well described (Durigon and Paolaggi, 1991; Lagier, 1991; Kumagai et al., 1994; Jiang et al., 2002; Milz et al., 2004; Benjamin et al., 2007, 2009). They are:

- Microtears or microdamage of one of the four histological zones of the enthesis (tendon, uncalcified and calcified fibrocartilage, bone);

- Formation of enthesophytes (bony spurs at the enthesis), induced by the healing process, after microtears;

- Disturbance of collagen fibers and of the organization of cell columns;

- Calcific deposits;

- Increase of the thickness of the calcified fibrocartilage layer;

- Vascularization of the calcified and uncalcified fibrocartilage layers;

- Erosion of the surface and bone resorption beneath the enthesis.

Disturbance of enthesis organization and subsequent healing processes are visible on skeletal remains: vascularization, enthesophytes, calcific deposits, cysts, and irregularity of the surface are common in the skeletons of old individuals (Shaibani et al., 1993; Cunha and Umbelino, 1995; Mariotti et al., 2004, 2007; Villotte, 2009; Alves Cardoso and Henderson, 2010; Villotte et al., 2010a; Milella et al., 2012. Bony spur formation typically occurs in the most fibrous part of an enthesis (Villotte, 2006; Benjamin et al., 2009). It should be noted that, contrary to other fibrocartilaginous entheses, there is no correlation between frequency and size of enthesophytes at the ligamenta flava attachment sites and age-at-death (Cunha and Umbelino, 1995; Villotte, 2009).

Excessive mechanical stress in terms of frequency, speed and/or intensity can cause a series of micro-traumatic insults that tend to disturb the tissue structure of the fibrocartilaginous enthesis (Husson et al., 1991; Khan et al., 1999; Benjamin et al., 2006). In young adults, these mechanical stresses are the main factor in the occurrence of an activity-related enthesopathy (Rodineau, 1991). In the older individual, on the contrary, it is the gradual depletion of tendon vascularity close to the insertion that favours the occurrence of lesions (Rodineau 1991). Biomechanical parameters are, in this case, a secondary factor. Other factors may increase the 
risk of developing enthesopathy, for instance cold temperatures, the use of unsuitable equipment, very heavy muscular stresses endured without training or appropriate warm-up, and abnormal structures disrupting joint biomechanics (Commandré, 1977; Rodineau, 1991; Bard 2003). The work of several authors, including Khan and collaborators (1999) and Milz and collaborators (2004), clearly indicate that overuse enthesopathies are similar to degenerative ones described in older individuals. Thus, micro- and macro-bony avulsions, tidemark irregularity (disorganization of the layer of calcified fibrocartilage), vascularisation of the fibrocartilage, calcification, and ossification of soft tissues can be observed in cases of overuse enthesopathy (Dupont et al., 1983; Husson et al., 1991; Saillant et al., 1991; Potter et al., 1995; Selvanetti et al., 1997). It is noteworthy that in these sports medicine reports, skeletal alterations are, in most cases, inconspicuous.

Sports and occupational injuries at tendons and entheses seem, at present, more common in women (Punnett and Herbert, 2000; Bard, 2003). However, these differences are not observed for all anatomical sites and many sex-related parameters (e.g. muscle mass, fat mass, size, morphology), may interact (e.g. Punnett and Herbert, 2000; Bard, 2003). Among the factors involved, ovarian hormones, including estradiol and relaxin, could play an important role. The contribution of these hormones in reducing the amount of glycosaminoglycans and collagen has been demonstrated for fibrocartilaginous joints (Naqvi et al., 2005; Hashem et al., 2006). Moreover, these hormones promote hyper-laxity and increase the risk of intrinsic mechanical lesions (Punnett and Herbert, 2000; Bard, 2003). At the menopause, blood levels of estrogen drop significantly (Sowers, 2000). This decrease causes a change in the composition of collagen connective tissue, including ligaments, associated with loss of elasticity (Falconer et al., 1996; Ewies et al., 2003).

\section{2) Diaphyses}

As for fibrocartilaginous entheses, the following discussion on properties of fibrous entheses during skeletal immaturity is based on animal models. These models are of two kinds: those focusing on gross anatomy and those studying the histological properties of these entheses. The first type indicates that during growth, there is a relationship between muscle activity/properties and the morphology of attachment sites. For instance, Dyzart and colleagues (1989) demonstrated that denervation of the rat forelimb is followed by an abnormally formed humerus, notably a smaller and less curved deltoid tuberosity. Based on these findings they postulated "that muscle pull affects periosteal tension and consequently 
bone form and growth in length" (Dyzart et al., 1989: 158). In a study of mutant strains of mice, Montgomery and colleagues (2005: 819) reached a slightly different conclusion: "These findings suggest that muscle attachment sites expand during growth in order to accommodate increases in muscle size and mass, but that expansion of these bony regions is not necessarily dependent on increases in muscle contractile strength [...]".

If these experiments provide interesting insights into the effects of muscle properties and activity on bone morphology, the study of histological properties of attachment sites appears more informative for a better understanding of the "normal" appearance of fibrous entheses in the immature human skeleton. In dog, rabbit and rat studies on diaphyseal entheses, tendons and ligaments attach via periosteum during growth (Laros et al., 1971; Dörfl, 1980a, 1980b; Hurov, 1986; Matyas et al., 1990; Gao et al., 1996; Wei and Messner, 1996). Both osteoclastic and osteoblastic activity are seen at fibrous attachment sites during this period and appear to be mainly related to the migration of the attachments of tendons and ligaments during the growth in length of long bones (Hoyte and Enlow, 1966; Dörfl, 1980a, 1980b; Hurov, 1986). It is noteworthy that muscular traction plays no role in this migration (Dörfl, 1980a, 1980b; Grant et al., 1981). All these animal model studies included the tibial insertion of the medial collateral ligament. This ligament attaches to the tibia of growing individuals in an area called the "metaphyseal depression", where growth-related osteoclastic resorption is more predominant than osteoblastic activity (Dörfl, 1980a; Matyas et al., 1990; Wei and Messner, 1996). Osteoclasts are most obvious at the periosteal side of the bone but they are also seen at the endosteal or marrow side (Wei and Messner, 1996). It is noteworthy that the "metaphyseal depression" disappears in mature rabbits (Matyas et al., 1990), but a shallow depression persists in rats up to 120 days of age, which was interpreted by Wei and Messner (1996) as a sign of continuing growth. Many biological anthropologists (e.g. Saunders, 1978; Castex, 1990; Stirland, 1996; Mariotti et al., 2004) reported high frequencies of a "fossa" in juveniles and young adults for several metaphyseal attachment sites (e.g. humeral insertions of the Mm. pectoralis major and teres major and the femoral insertion of the M. gluteus maximus). Actually, these grooves or "fossae" are very common in immature human skeletons, in frequency but also in their distribution in the body (Fig. 5), and it may be tentatively suggested that they are related to a process similar to that described for the tibial "metaphyseal depression" in rats and rabbits. These changes, especially for the humeral insertion of the $M$. pectoralis major, seem to be more dramatic in males during late adolescence and early adulthood, before the complete fusion of the epiphysis (Mariotti et al., 2004). Consequently, linking these erosions in young adult males solely to mechanical 
stresses (e.g. Hawkey and Merbs, 1995) appears, at least, highly hazardous (see Villotte, $2008 \mathrm{~b}$ for a review of the possible causes of a "fossa" at the humeral insertion of the $M$. pectoralis major in adults). Moreover, the bottom of these grooves is usually not smooth in juvenile human skeletons: marked porosity, short striae and small asperities are often present (Villotte, 2006). One could speculate that those changes are related to the irregularity of the mineralization front (i.e. the superficial cortex) before skeletal maturity in other mammals (Matyas et al., 1990; Wei and Messner, 1996).

\section{FIGURE 5}

In mature animals the periosteal layer may or may not disappear, depending on the species and the enthesis. In adult humans, periosteal fibrous entheses are seen where muscles attach to a large area by short fibrous ends (Kenesi and Tallineau, 1991), and for some masticatory muscles (Hems and Tillmann, 2000). As the mediating layer of periosteum often disappears with age and leaves the soft tissue attaching directly to bone (Benjamin et al., 2002), it has been hypothesized that the physiological transition from a periosteal to a bony attachment in early adulthood may explain the high frequency of skeletal changes (i.e. irregularity) seen in young/middle-aged adults (Villotte 2009).

Benjamin and collaborators (2002: 934) note that "relatively little attention has been paid to fibrous entheses, even though they are associated with some of the largest and most powerful muscles in the body [...]. This partly reflects a clinical bias toward fibrocartilaginous entheses - which are more vulnerable to overuse injuries, but also the attraction of working with a richer variety of tissues that such entheses can offer." In a study that focuses mainly on fibrocartilaginous entheses, Benjamin and collaborators (2007) briefly describe two modifications observed in elderly subjects at the fibrous insertion of $M$. pronator teres: a bony production and a vascular invasion of the fibrous tissue. Micro-trauma at fibrous entheses are described mainly for periosteal attachment sites (e.g. Condouret and Pujol, 1985); they lead to a periostitis. Only a few cases were reported for bony ones: enthesopathy at the $M$. deltoideus insertion on the humerus in golfers and "pala" players (Commandré, 1977: 67) and small resorptive areas at the humeral insertion of the M. pectoralis major in gymnasts (Fulton et al., 1979). 
To conclude this section, it seems important to report an interesting study on the effect of inactivity for several entheses in dogs (Laros et al., 1971). In active immature dogs, normal metaphyseal remodelling was seen with a marked bone resorption at the tibial insertion of the medial collateral ligament (i.e. a normal appearance, cf. supra). In inactive adolescent dogs, the reaction was more generalized. Contrary to the other entheses under study, simple caging for six weeks produced resorption at the tibial insertion of the medial collateral ligament in adult dogs. Moreover, after several weeks of immobilization in a plaster cast, resorptive changes at this enthesis were seen for the immobilized limb of adult dogs, but also in a lesser extent for the non-immobilized limb, free for activity and weight-bearing! With continued caging (over a period of six months or more) and in dogs sacrificed twelve weeks after removal of plaster immobilization, bone resorption healed as fibrous tissue replaced resorbed bone and then became mineralized.

\section{Conclusion}

In the last twenty years, researchers have published important works on the limits and pitfalls of interpretations of entheseal changes as activity markers (e.g. Dutour, 1992; Jurmain, 1999; Jurmain et al., 2012), mainly related to the problem of false positives (in our case, an entheseal change not related to physical activity). Based on our experience, exuberant bone production is mainly seen in older individuals, individuals with systemic disease or, locally, in cases of trauma. In many cases major entheseal changes are probably not directly related to physical activity, and certainly not only to micro-trauma at the enthesis.

While some biological anthropologists seem to have been completely unaware of these problems, others, notably Weiss (2003, 2004; Weiss et al., 2012), have attempted to identify the "confounding" factors, but without adequately documented material. The archaeological record does not represent the best samples from which to identify the processes that produce alterations of an attachment site, for at least one good reason: the age-at-death assessment. This contribution illustrates the usefulness of clinical studies and studies based on identified skeletal collections for the understanding of entheseal changes. Based on the data obtained thus far, it seems that most of the changes seen for fibrous entheses cannot be directly associated with activity. In fact, some of the most common changes considered in biological anthropology - cortical defects at metaphyseal sites - may be related to growth and development, or even to inactivity. This hypothesis was formulated previously by Mafart (1996), though on archaeological criteria. If the study of enthesopathies for fibrocartilaginous 
sites appears more promising to attempt to reconstruct past activities, one cannot deny the numerous difficulties associated with their recording and the multiple factors leading to their appearance in the human skeleton.

Acknowledgements

The authors thank Charlotte Henderson and Francisca Alves-Cardoso for the invitation to participate in the Symposium and the two reviewers for their useful comments.

References cited

Adirim T, and Cheng T. 2003. Overview of injuries in the young athlete. Sports Medicine 33 : $75-81$.

Alves Cardoso F, and Henderson CY. 2010. Enthesopathy formation in the humerus: Data from known age-at-death and known occupation skeletal collections. American Journal of Physical Anthropology 141 : 550-560.

Angel JL, Kelley JO, Parrington M, and Pinter S. 1987. Life stresses of the free Black community as represented by the First African Baptist Church, Philadelphia, 1823-1841. American Journal of Physical Anthropology 74 : 213-229.

Ball J. 1971. Enthesopathy of rheumatoid and ankylosing spondylitis. Annals of the Rheumatic Diseases 30 : 213-223.

Bard H. 2003. Physiopathologie, réparation, classification des tendinopathies mécaniques. In Tendons et enthèses, Bard H, Cotten A, Rodineau J, Saillant G, and Railhac J-J (eds). Sauramps Médical: Montpellier; 165-178.

Benjamin M, Evans EJ, and Copp L. 1986. The histology of tendon attachments to bone in man. Journal of Anatomy $149: 89-100$.

Benjamin M, Newell RL, Evans EJ, Ralphs JR, and Pemberton DJ. 1992. The structure of the insertions of the tendons of biceps brachii, triceps and brachialis in elderly dissecting room cadavers. Journal of Anatomy $180: 327-332$.

Benjamin M, Kumai T, Milz S, Boszczyk BM, Boszczyk AA, and Ralphs JR. 2002. The skeletal attachment of tendons - tendon "entheses". Comparative Biochemistry and Physiology, Part A: Molecular \& Integrative Physiology 133 : 931-945.

Benjamin M, and McGonagle D. 2001. The anatomical basis for disease localisation in seronegative spondyloarthropathy at entheses and related sites. Journal of Anatomy 199 : 503526.

Benjamin M, Moriggl B, Brenner E, Emery P, McGonagle D, and Redman S. 2004. The "enthesis organ" concept: why enthesopathies may not present as focal insertional disorders. Arthritis \& Rheumatism 50 : 3306-3313.

Benjamin M, Toumi H, Ralphs JR, Bydder G, Best TM, and Milz S. 2006. Where tendons and ligaments meet bone: attachment sites ("entheses") in relation to exercise and/or mechanical load. Journal of Anatomy 208 : 471-490.

Benjamin M, Toumi H, Suzuki D, Redman S, Emery P, and McGonagle D. 2007. Microdamage and altered vascularity at the enthesis-bone interface provides an anatomic explanation for bone involvement in the HLA-B27-associated spondylarthritides and allied disorders. Arthritis \& Rheumatism $56: 224-233$. 
Benjamin M, Toumi H, Suzuki D, Hayashi K, and McGonagle D. 2009. Evidence for a distinctive pattern of bone formation in enthesophytes. Annals of the Rheumatic Diseases 68 : 1003-1010.

Castex D. 1990. Insertion du grand pectoral et du grand rond sous forme de fosse. Bulletins et Mémoires de la Société d'Anthropologie de Paris n.s., 2 : 185-190.

Condouret J, and Pujol M. 1985. Périostites tibiales. In Muscles, tendons et sport, Bénézis C, Simeray J, and Simon L (eds). Masson: Paris; 113-119.

Cooper RR, and Misol S. 1970. Tendon and ligament insertion. A light and electron microscopic study. The Journal of Bone and Joint Surgery [Am] 52: 1-20.

Cunha E, and Umbelino C. 1995. What can bones tell about labour and occupation: the analysis of skeletal markers of occupational stress in the Identified Skeletal Collection of the Anthropological Museum of the University of Coimbra (preliminary results). Antropologia Portuguesa 13 : 49-68.

de Pinieu G, and Forest M. 2003. Qu'est-ce qu'une enthèse ? In Tendons et enthèses, Bard H, Cotten A, Rodineau J, Saillant G, and Railhac J-J (eds). Sauramps Médical: Montpellier; 1517.

Dörfl J. 1969. Vessels in the region of tendinous insertions. II. Diaphysoperiosteal insertion. Folia Morphologica 17 : 79-82.

Dörfl J. 1980a. Migration of tendinous insertions. I. Cause and mechanism. Journal of Anatomy $131:$ : 179-195.

Dörfl J. 1980b. Migration of tendinous insertions. II. Experimental modifications. Journal of Anatomy $131:$ 229-237.

Dupont M, Pasteels JL, Duchateau M, and Szpalski M. 1983. Tendinites corporéales et ostéotendinites, essai de définition des lésions et de leur traitement chirurgical. Acta Orthopeedica Belgica 49 : 30-41.

Durigon M, and Paolaggi J-B. 1991. Enthèse au cours de la vie. In Pathologie des insertions et enthésopathies, Simon L, Hérisson C, and Rodineau J (eds). Masson: Paris; 12-17.

Dutour O. 1986. Enthesopathies (lesions of muscular insertions) as indicators of the activities of Neolithic Saharan populations. American Journal of Physical Anthropology 71 : 221-224.

Dutour O. 1992. Activités physiques et squelette humain : le difficile passage de l'actuel au fossile. Bulletins et Mémoires de la Société d'Anthropologie de Paris n.s., $4: 233-241$.

Dutour O. 2000. Chasse et activités physiques dans la Préhistoire : les marqueurs osseux d'activités chez l'homme fossile. Anthropologie et Préhistoire 111 : 156-165.

Dysart PS, Harkness EM, and Herbison GP. 1989. Growth of the humerus after denervation. An experimental study in the rat. Journal of Anatomy 167 : 147-159.

Ewies AAA, Al-Azzawi F, and Thompson J. 2003. Changes in extracellular matrix proteins in the cardinal ligaments of post-menopausal women with or without prolapse: a computerized immunohistomorphometric analysis. Human Reproduction 18 : 2189-2195.

Falconer C, Ekman-Ordeberg G, Ulmsten U, Westergren-Thorsson G, Barchan K, and Malmström A. 1996. Changes in paraurethral connective tissue at menopause are counteracted by estrogen. Maturitas $24: 197-204$.

Forestier J, and Rotes-Querol J. 1950. Senile Ankylosing Hyperostosis of the Spine. Annals of the Rheumatic Diseases $9:$ 321-330.

Fournié B. 2004. Pathology and clinico-pathologic correlations in spondyloarthropathies. Joint Bone Spine 71 : 525-529.

Fournié B, and Fournié A. 1991. Elargissement du concept d'enthèse. In Pathologie des insertions et enthésopathies, Simon L, Hérisson C, and Rodineau J (eds). Masson: Paris; 1821.

François RJ, Braun J, and Khan MA. 2001. Entheses and enthesitis: a histopathologic review and relevance to spondyloarthritides. Current Opinion in Rheumatology 13 :255-264. 
Fulton MN, Albright JP, and El-Khoury GY. 1979. Cortical desmoid-like lesion of the proximal humerus and its occurrence in gymnasts (ringman's shoulder lesion). The American Journal of Sports Medicine 7 : 57-61.

Gao J, Messner K, Ralphs JR, and Benjamin M. 1996. An immunohistochemical study of enthesis development in the medial collateral ligament of the rat knee joint. Anatomy and Embryology 194 : 399-406.

Grant PG, Bushang PH, Drolet DW, and Pickerell C. 1981. The effect of changes in muscle function and bone growth on muscle migration. American Journal of Physical Anthropology $54: 547-553$.

Hashem G, Zhang Q, Hayami T, Chen J, Wang W, and Kapila S. 2006. Relaxin and betaestradiol modulate targeted matrix degradation in specific synovial joint fibrocartilages: progesterone prevents matrix loss. Arthritis Research \& Therapy 8 : R98.

Havelková P, Villotte S, Velemínský P, Poláček L, and Dobisíková M. 2011. Enthesopathies and activity patterns in the Early Medieval Great Moravian population: Evidence of division of labour. International Journal of Osteoarchaeology 21 : 487-504.

Hawkey DE. 1988. Use of upper extremety enthesopathies to indicate habitual activity patterns. M.A. thesis: Arizona State University.

Hawkey DE, and Merbs CF. 1995. Activity-induced musculoskeletal stress markers (MSM) and subsistence strategy changes among ancient Hudson Bay Eskimos. International Journal of Osteoarchaeology $5: 324-338$.

Hems T, and Tillmann B. 2000. Tendon entheses of the human masticatory muscles. Anatomy and Embryology 202 : 201-208.

Henderson CY. 2008. When hard work is disease: the interpretation of enthesopathies. In Proceedings of the 8th annual conference of the British Association of Biological Anthropology and Osteoarchaeology, Brickley M, and Smith M (eds). Archaeopress: Oxford; 17-25.

Henderson CY, and Gallant AJ. 2007. Quantitative recording of entheses. Paleopathology Newsletter 137 : 7-12.

Henderson CY, Mariotti V, Pany-Kucera D, Perréard-Lopreno G, Villotte S, and Wilczak CA. 2010. Scoring entheseal changes: proposal of a new standardised method for fibrocartilaginous entheses. Poster presented at the 18th European Meeting of the Paleopathology Association, Vienna, Austria 23rd-26th of August 2010. Consulted in 25th May 2012. Available from: https://www.uc.pt/en/cia/msm/Vienna2010.pdf.

Hoyte DAN, and Enlow DH. 1966. Wolff's law and the problem of muscle attachment on resorptive surface of bone. American Journal of Physical Anthropology 24 : 205-214.

Hurov JR. 1986. Soft-tissue bone interface: How do attachments of muscles, tendons, and ligaments change during growth? A light microscopic study. Journal of Morphology 189 : 313-325.

Husson JL, Chauveaux D, Rochcongar P, and Lancien G. 1991. Physiopathologie et anatomopathologie des enthésopathies d'insertion par sollicitations mécaniques du système tendinomusculaire. In Pathologie des insertions et enthésopathies, Simon L, Hérisson C, and Rodineau J (eds). Masson: Paris; 156-166.

Jiang Y, Zhao J, van Holsbeeck MT, Flynn MJ, Ouyang X, and Genant HK. 2002. Trabecular microstructure and surface changes in the greater tuberosity in rotator cuff tears. Skeletal Radiology 31 : 522-528.

Jurmain R. 1999. Story from the skeleton. Gordon and Breach Publishers: Amsterdam.

Jurmain R, Alves Cardoso F, Henderson CY, and Villotte S. 2012. Bioarchaeology's Holy Grail: The Reconstruction of Activity. In A Companion to Paleopathology, Grauer AL (ed.). Wiley-Blackell: New-York; 531-552. 
Jurmain R, and Roberts C. 2008. Juggling the evidence: the purported 'acrobat' from Tell Brak. Antiquity 82. Consulted in 29th May 2012. Available from: http://www.antiquity.ac.uk/ProjGall/jurmain/index.html

Jurmain R, and Villotte S. 2010. Terminology. Entheses in medical literature and physical anthropology: a brief review. Document published online in 4th February following the Workshop in Musculoskeletal Stress Markers (MSM): limitations and achievements in the reconstruction of past activity patterns, University of Coimbra, July 2-3, 2009. Coimbra, CIAS - Centro de Investigação em Antropologia e Saúde. Consulted in 29th May 2012. Available from: http://www.uc.pt/en/cia/msm/MSM_terminology3.pdf

Kenesi C, and Tallineau C. 1991. Anatomie et biomécanique des enthèses. In Pathologie des insertions et enthésopathies, Simon L, Hérisson C, and Rodineau J (eds). Masson: Paris; 8-12. Kennedy KAR. 1989. Skeletal markers of occupational stress. In Reconstruction of life from the skeleton, Iscan MY, and Kennedy KAR (eds). Liss: New York; 130-160.

Khan KM, Cook JL, Bonar F, Harcourt P, and Åstrom M. 1999. Histopathology of common tendinopathies. Update and implications for clinical management. Sports Medicine 27 : 393408.

Knüsel CJ. 2012. Men Take Up Arms for War: Sex and Status Distinctions of Humeral Medial Epicondylar Avulsion Fractures in the Archaeological Record. In Breathing New Life into the Evidence of Death Contemporary Approaches to Bioarchaeology, Baadsgaard A, Boutin AT, and Buikstra JE (eds). School for Advanced Research Press: New Mexico; 223251.

Kumagai J, Sarkar K, and Uhthoff HK. 1994. The collagen types in the attachment zone of rotator cuff tendons in the elderly: an immunohistochemical study. Journal of Rheumatology $21: 2096-2100$.

La Cava G. 1959. Enthesitis-traumatic disease of insertions. Journal of the American Medical Association $169: 254-255$.

Lagier R. 1991. Enthèses normales et enthésopathies. In Pathologie des insertions et enthésopathies, Simon L, Hérisson C, and Rodineau J (eds). Masson: Paris; 1-6.

Lane WA. 1887. A remarkable example of the manner in which pressure-changes in the skeleton may reveal the labour history of the individual. Journal of Anatomical Physiology 21 : 385-406.

Lane WA. 1888. Anatomy and physiology of the shoemaker. Journal of Anatomical Physiology 22 : 592-628.

Laros GS, Tipton CM, and Cooper RR. 1971. Influence of physical activity on ligament insertions in the knees of dogs. The Journal of Bone and Joint Surgery [Am] 53 : 275-286.

Mafart B-Y. 1996. Quelques particularités anthropologiques et paléopathologiques d'une population de moniales médiévales de l'abbaye de Saint-Pierre de l'Almanarre (XIIIe-XIVe siècles, Hyères, Var). In L'identité des populations archéologiques. Actes des XVIe rencontres internationales d'archéologie et d'histoire d'Antibes, L. Buchet (ed.). Éditions APDCA: Sophia-Antipolis ; 271-286.

Mariotti V, Facchini F, and Belcastro MG. 2004. Enthesopathies - Proposal of a standardized scoring method and applications. Collegium Antropologicum 28 : 145-159.

Mariotti V, Facchini F, and Belcastro MG. 2007. The study of entheses: proposal of a standardised scoring method for twenty-three entheses of the postcranial skeleton. Collegium Antropologicum 31 : 191-313.

Matyas JR, Bodie D, Andersen M, and Frank CB. 1990. The development morphology of a "periosteal" ligament insertion: Growth and maturation of the tibial insertion of the rabbit medial collateral ligament. Journal of Orthopaedic Research 8 : 412-424. 
Milella M, Giovanna Belcastro M, Zollikofer CPE, and Mariotti V. 2012. The effect of age, sex, and physical activity on entheseal morphology in a contemporary Italian skeletal collection. American Journal of Physical Anthropology 148: 379-388.

Milz S, Tischer T, Buettner A, Schieker M, Maier M, Redman S, Emery P, McGonagle D, and Benjamin M. 2004. Molecular composition and pathology of entheses on the medial and lateral epicondyles of the humerus: a structural basis for epicondylitis. Annals of the Rheumatic Diseases 63 : 1015-1021.

Molnar P. 2006. Tracing prehistoric activities: musculoskeletal stress marker analysis of a stone-age population on the Island of Gotland in the Baltic sea. American Journal of Physical Anthropology $129: 12-23$.

Montgomery E, Pennington C, Isales CM, and Hamrick MW. 2005. Muscle-bone interactions in dystrophin-deficient and myostatin-deficient mice. The Anatomical Record Part A:

Discoveries in Molecular, Cellular, and Evolutionary Biology 286A : 814-822.

Nakanishi K, Masatomi T, Ochi T, Ishida T, Hori S, Ikezoe J, and Nakamura H. 1996. MR arthrography of elbow: evaluation of the ulnar collateral ligament of elbow. Skeletal Radiology 25 : 629-634.

Naqvi T, Duong TT, Hashem G, Shiga M, Zhang Q, and Kapila S. 2005. Relaxin's induction of metalloproteinases is associated with the loss of collagen and glycosaminoglycans in synovial joint fibrocartilaginous explants. Arthritis Research \& Therapy 7 : R1 - R11.

Nawata K, Minamizaki T, Yamashita Y, and Teshima R. 2002. Development of the attachment zones in the rat anterior cruciate ligament: changes in the distributions of proliferating cells and fibrillar collagens during postnatal growth. Journal of Orthopaedic Research 20 : 1339-1344.

Niepel GA, and Sit'Aj S. 1979. Enthesopathy. Clinics in Rheumatic Diseases 5 : 857-872.

Niinimäki S. 2011. What do muscle marker ruggedness scores actually tell us? International Journal of Osteoarchaeology $21: 292-299$.

Paolaggi J-B, Struz P, Goutet MC, Le Parc JM, Siaud JR, and Auquier L. 1984a. Recherche systématique des enthésopathies au cours des rhumatismes chroniques. Résultats et signification pathologique. Revue du Rhumatisme et des Maladies Ostéo-articulaires 51 : 451-456.

Paolaggi J-B, Struz P, Siaud JR, Le Parc JM, and Auquier L. 1984b. Les enthésopathies des spondyloarthropathies inflammatoires. Revue du Rhumatisme et des Maladies Ostéoarticulaires $51:$ 457-462.

Polster J, Elgabaly M, Lee H, Klika A, Drake R, and Barsoum W. 2008. MRI and gross anatomy of the iliopsoas tendon complex. Skeletal Radiology 37 : 55-58.

Potter HG, Hannafin JA, Morwessel RM, DiCarlo EF, O'Brien SJ, and Altchek DW. 1995. Lateral epicondylitis: correlation of MR imaging, surgical and histopathologic findings. Radiology 196 : 43-46.

Punnett L, and Herbert R. 2000. Work-related musculoskeletal disorders: is there a gender differential, and if so, what does it mean? In Women and Health, Goldman MB, and Hatch M, (eds). Academic Press: San Diego; 474-492.

Resnick D, Shaul S, and Robins JM. 1975. Diffuse idiopathic skeletal hyperostosis (DISH): Forestier's disease with extraspinal manifestations. Radiology 115 : 513-524.

Resnick D, and Niwayama G. 1983. Entheses and enthesopathy. Radiology 146 : 1-9. Riley G. 2004. The pathogenesis of tendinopathy. A molecular perspective. Rheumatology 43 : 131-142.

Robb JE. 1998. The interpretation of skeletal muscle sites: a statistical approach. International Journal of Osteoarchaeology $8: 363-377$. 
Rodineau J. 1991. Pathogénie des enthésopathies du membre supérieur. In Pathologie des insertions et enthésopathies, Simon L, Hérisson C, and Rodineau J (eds). Masson: Paris; 166171.

Saillant G, Thoreux P, Vandenbussche E, and Roy-Camille R. 1991. Aspect macroscopique des enthésites. Rapport avec le socle osseux. Bursites associés. In Pathologie des insertions et enthésopathies, Simon L, Hérisson C, and Rodineau J (eds). Masson: Paris; 149-151.

Santos AL, Alves Cardoso F, Assis S, and Villotte S. 2011. The Coimbra Workshop in Musculoskeletal Stress Markers (MSM): an annotated review. Antropologia Portuguesa 28 : 135-161.

Saunders SR. 1978. The development and distribution of discontinuous morphological variation of the human infracranial skeleton. National Museums of Canada, Archaeological Survey of Canada: Ottawa.

Selvanetti A, Cipolla M, and Puddu G. 1997. Overuse tendon injuries: basic science and classification. Operative Techniques in Sports Medicine 5 : 110-117.

Shaibani A, Workman R, and Rothschild BM. 1993. The significance of enthesopathy as a skeletal phenomenon. Clinical and Experimental Rheumatology 11 : 399-403.

Shaw HM, Vázquez OT, McGonagle D, Bydder G, Santer RM, and Benjamin M. 2008. Development of the human Achilles tendon enthesis organ. Journal of Anatomy 213 : 718724.

Sowers MR. 2000. Menopause: its epidemiology. In Women and health, Goldman MB, and Hatch M (eds). Academic Press: San Diego; 1155 -1168.

Stevens MA, El-Khoury GY, Kathol MH, Brandser EA, and Chow S. 1999. Imaging features of avulsion injuries. Radiographics $19: 655-672$.

Stirland AJ. 1996. Femoral non-metric traits reconsidered. Anthropologie 34 : 249-252.

Testut L. 1889. Recherches anthropologiques sur le squelette quaternaire de Chancelade (Dordogne). Pitrat aîné: Lyon.

Villotte S. 2006. Connaissances médicales actuelles, cotation des enthésopathies : nouvelle méthode. Bulletins et Mémoires de la Société d'Anthropologie de Paris n.s., 18 : 65-85.

Villotte S. 2008a. Les marqueurs ostéoarticulaires d'activité. In Ostéo-archéologie et techniques médico-légales : tendances et perspectives, Charlier P (ed.). Editions De Boccard: Paris; 383-389.

Villotte S. 2008b. L'insertion humérale «en fosse » du muscle grand pectoral. In Ostéoarchéologie et techniques médico-légales : tendances et perspectives, Charlier $\mathrm{P}$ (ed.). Editions De Boccard: Paris; 391-392.

Villotte S. 2009. Enthésopathies et activités des Hommes préhistoriques - Recherche méthodologique et application aux fossiles européens du Paléolithique supérieur et du Mésolithique. Archaeopress: Oxford.

Villotte S, and Kacki S. 2009. Remodelages des enthèses fibrocartilagineuses dans les spondylarthropathies inflammatoires Bulletins et Mémoires de la Société d'Anthropologie de Paris, ns $21: 159-169$.

Villotte S, Castex D, Couallier V, Dutour O, Knüsel CJ, and Henry-Gambier D. 2010a. Enthesopathies as occupational stress markers: evidence from the upper limb. American Journal of Physical Anthropology 142 : 224-234.

Villotte S, Churchill SE, Dutour O, Henry-Gambier D. 2010b. Subsistence activities and the sexual division of labor in the European Upper Paleolithic and Mesolithic: evidence from upper limb enthesopathies. Journal of Human Evolution 59 : 35-43.

Wang INE, Mitroo S, Chen FH, Lu HH, and Doty SB. 2006. Age-dependent changes in matrix composition and organization at the ligament-to-bone insertion. Journal of Orthopaedic Research 24 : 1745-1755. 
Wei X, and Messner K. 1996. The postnatal development of the insertions of the medial collateral ligament in the rat knee. Anatomy and Embryology 193 : 53-59.

Weiss E. 2003. Understanding muscle markers: aggregation and construct validity. American Journal of Physical Anthropology 121 : 230-240.

Weiss E. 2004. Understanding muscle markers: lower kimbs. American Journal of Physical Anthropology $125: 232-238$.

Weiss E, Corona L, and Schultz B. 2012. Sex differences in musculoskeletal stress markers: Problems with activity pattern reconstructions. International Journal of Osteoarchaeology 22 : 70-80.

Zumwalt A. 2005. A new method for quantifying the complexity of muscle attachment sites. The Anatomical Record Part B: The New Anatomist 286B : 21-28.

Zumwalt A. 2006. The effect of endurance exercise on the morphology of muscle attachment sites. The Journal of Experimental Biology 209 : 444-454. 


\begin{tabular}{|ll|}
\hline $\begin{array}{l}\text { Most common terms in biomedical } \\
\text { sciences }\end{array}$ & "Synonyms" \\
\hline Enthesis (plural: entheses) & Insertion site / Attachment site \\
& Insertion area / Attachment area \\
& Tendon-to-bone insertion / Ligament-to-bone \\
& insertion \\
& Zone of insertion / Zone of attachment \\
\hline Entheseal (adj.) & Enthesial* \\
& Enthesal \\
\hline Enthesopathy (plural: enthesopathies) & Enthesiopathy \\
& Insertiopathy \\
& Insertional tendinopathy \\
& Enthesopathic change \\
\hline Enthesitis (i.e. inflammation) & Insertitis \\
& Insertional tendinitis / Insertional tendonitis \\
& Insertional periostitis \\
\hline
\end{tabular}

Table 1. Common terminology used in biomedical sciences.

*: There is no consensus in favour of either "entheseal" or "enthesial" and both are in standard use. 


\section{Figure Captions}

Figure 1. Greater trochanter, insertion of the M. gluteus medius. Smooth imprint with regular margins. Scale: $1 \mathrm{~cm}$.

Figure 2. Lesser trochanter, insertion of the M. iliopsoas. White arrow: salient margin at the trochanter, taken into account in Villotte (2006). Black arrow: salient margin at the junction between the lesser trochanter and the femoral shaft, which can occur independently and was not taken into account in the same scoring system. Scale: $1 \mathrm{~cm}$.

Figure 3. Radial tuberosity. Changes occur at the medial part of the tuberosity - i.e. the attachment of the distal tendon of the M. biceps brachii (white arrow), and the lateral part that is the location of the bursa associated with this tendon (black arrow). Scale: $1 \mathrm{~cm}$.

Figure 4. Proximal humeral epiphysis of an immature individual (6-9 years old). The area of attachment of the M. supraspinatus and M.infraspinatus on the greater tubercle (white arrow) is not clearly distinguishable. Scale: $1 \mathrm{~cm}$.

Figure 5. Proximal tibial shaft of an immature individual (6-9 years old). The area of attachment of the M. soleus displays the classic appearance of immature metaphyseal entheses, a "fossa" with porosity, short striae and small asperities/irregularities at its bottom. Scale: $1 \mathrm{~cm}$. 


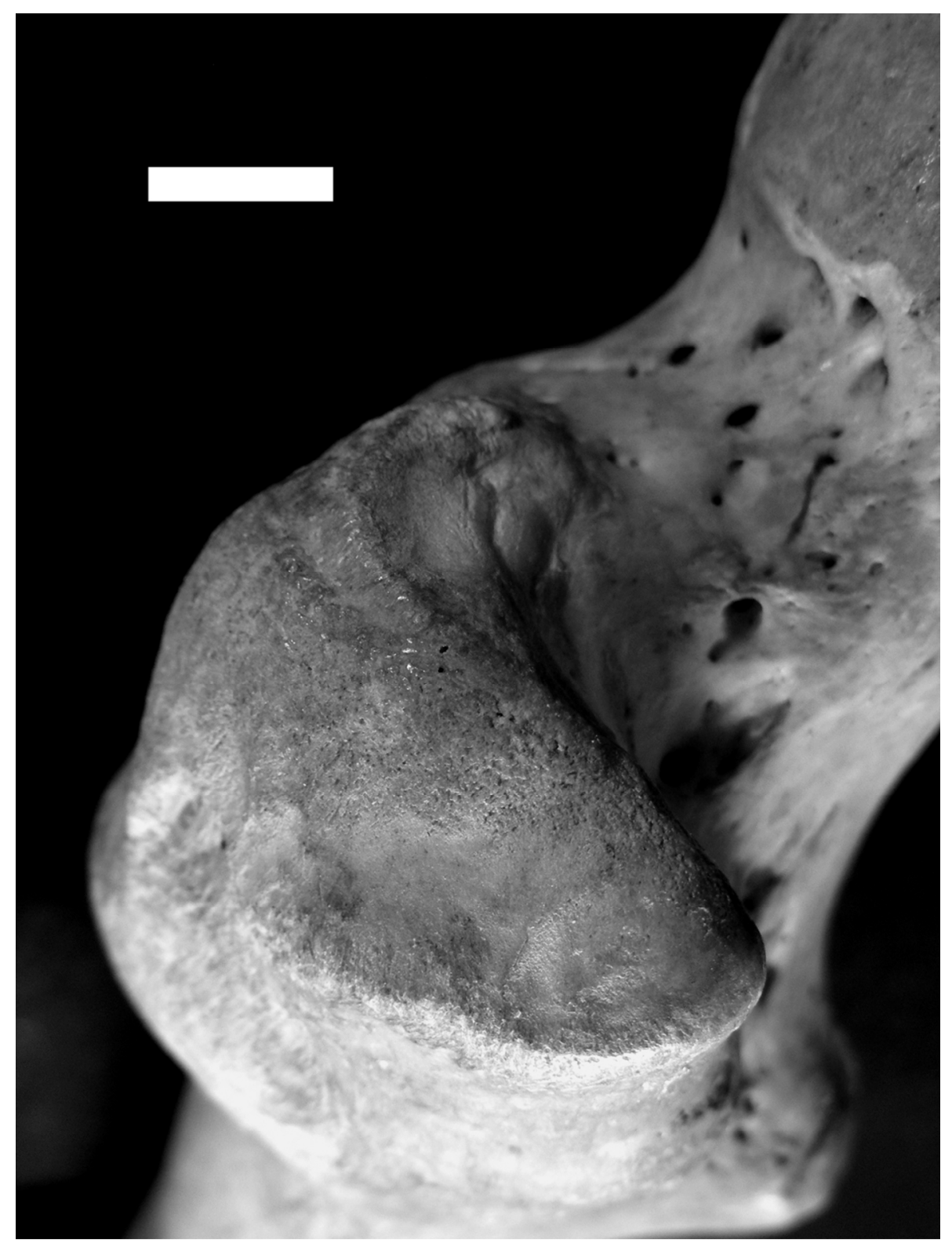

$119 \times 157 \mathrm{~mm}(300 \times 300 \mathrm{DPI})$ 


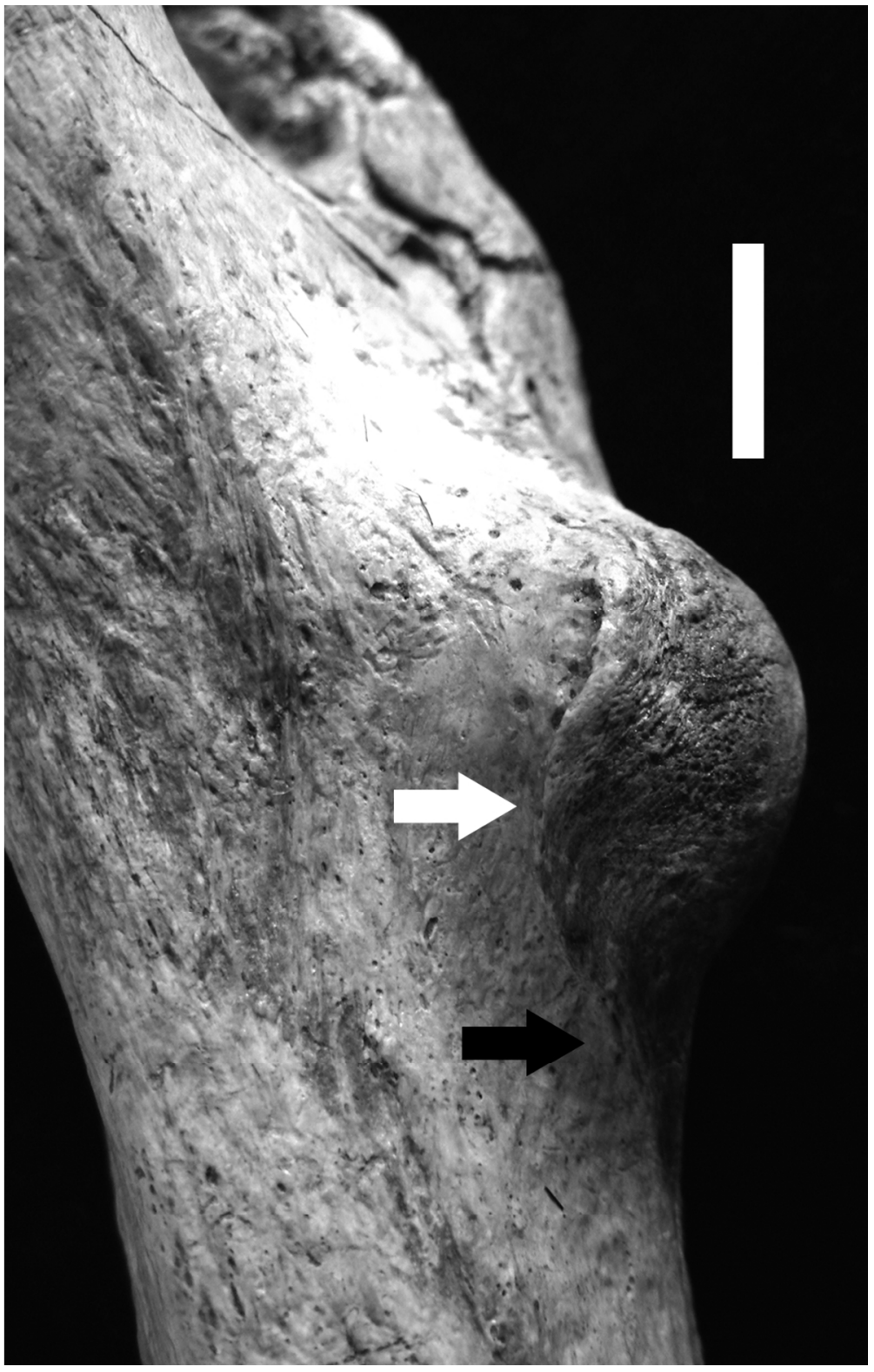

$90 \times 141 \mathrm{~mm}(300 \times 300 \mathrm{DPI})$ 


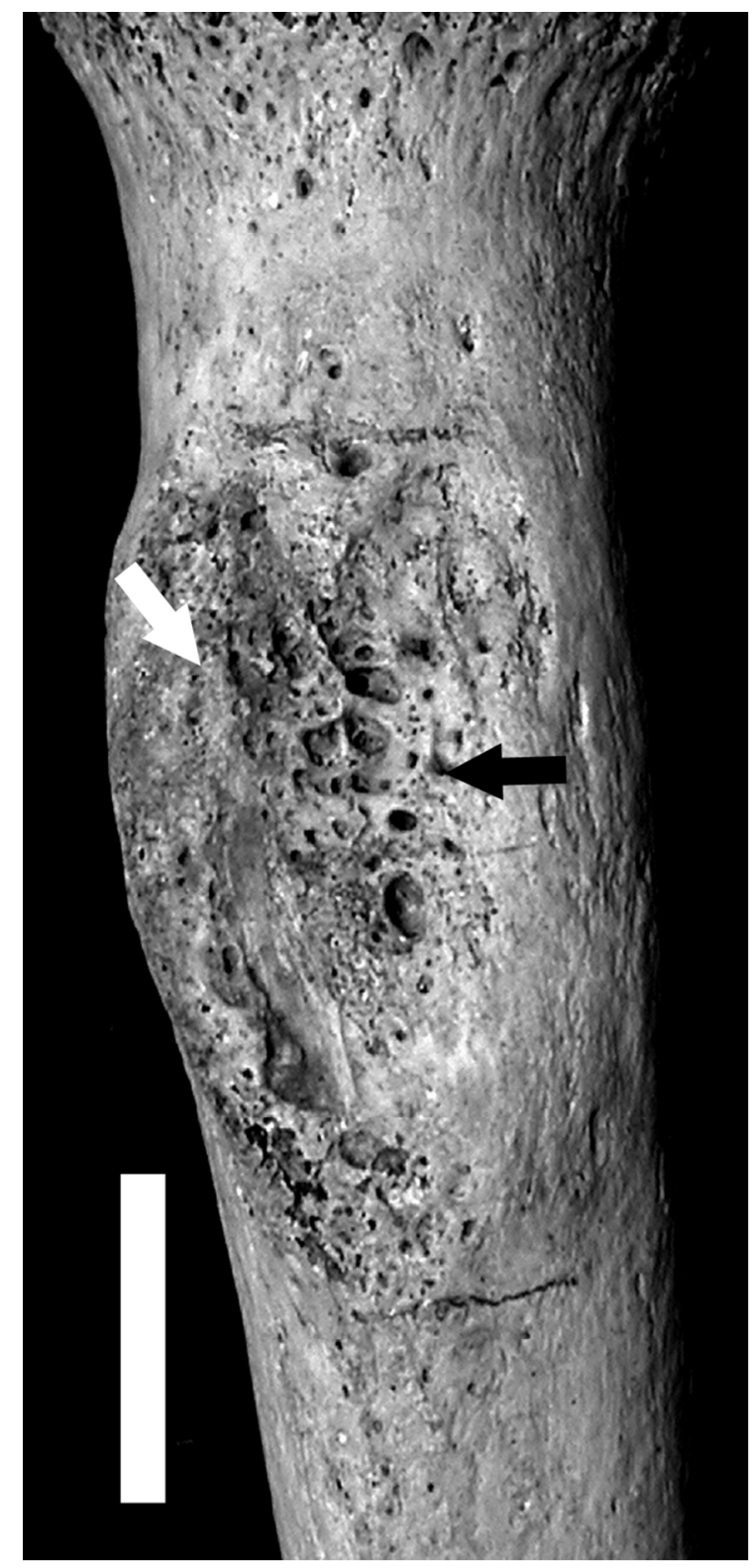

$60 \times 128 \mathrm{~mm}(300 \times 300$ DPI $)$ 


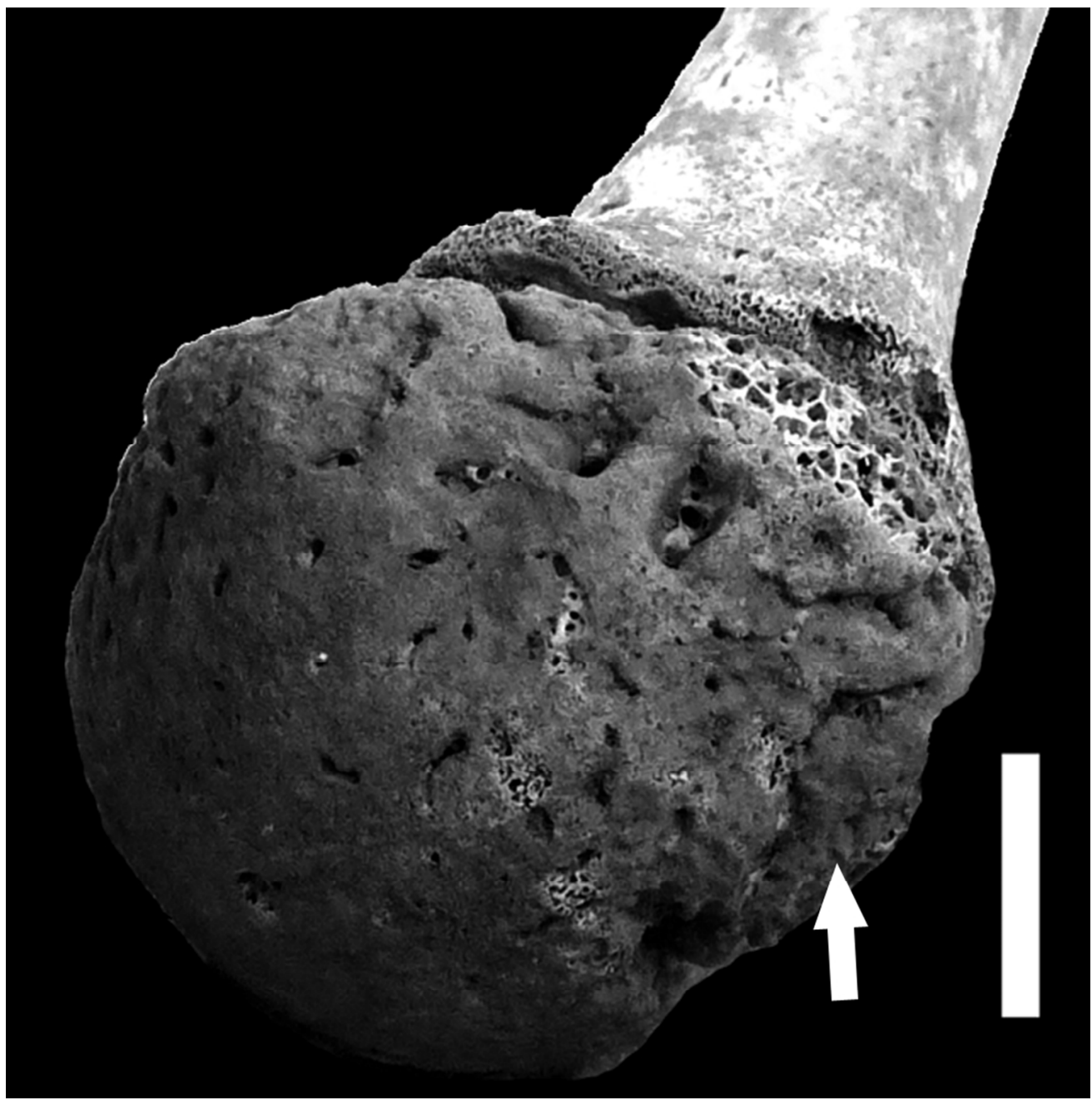

$90 \times 90 \mathrm{~mm}(300 \times 300 \mathrm{DPI})$ 


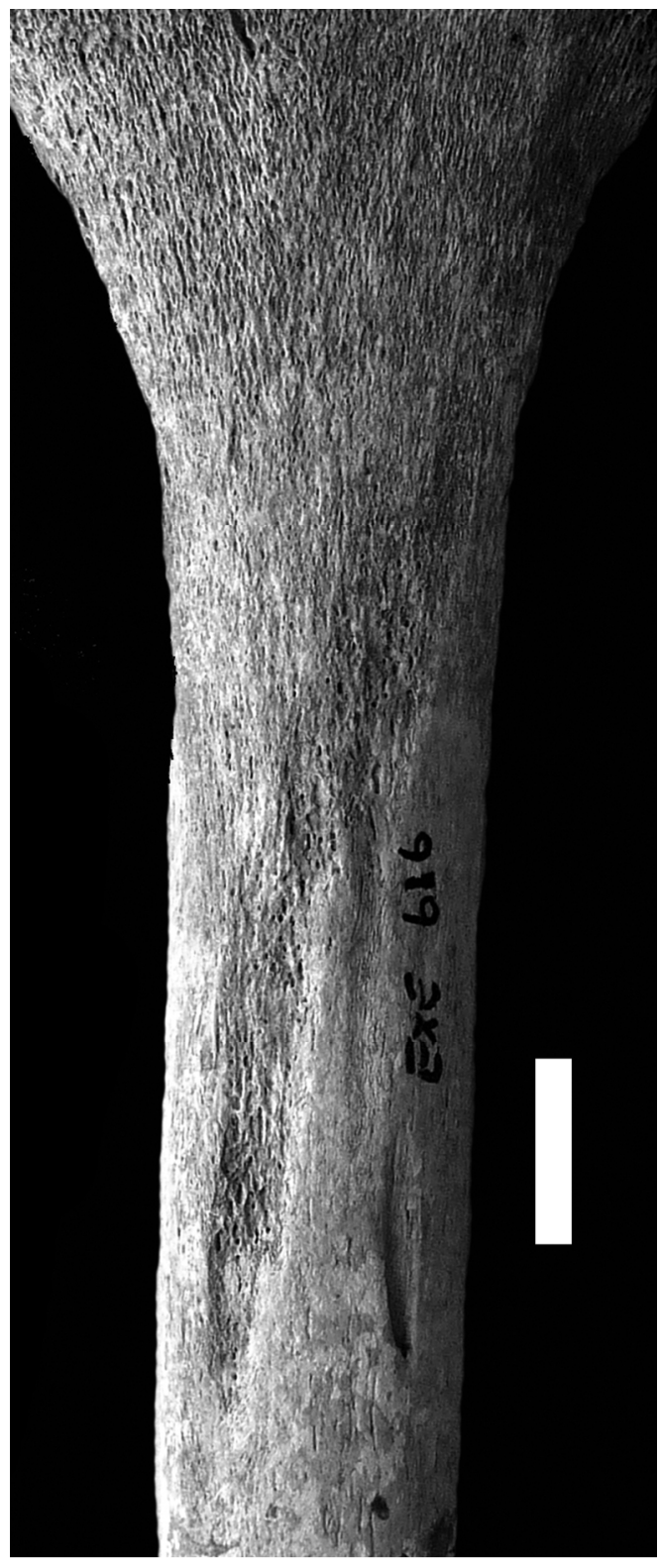

$119 \times 285 \mathrm{~mm}(300 \times 300 \mathrm{DPI})$ 